\title{
New distribution records of six species of Asilinae (Diptera: Asilidae) Latreille, 1802
}

\author{
Rodrigo Vieira \\ Instituto Nacional de Pesquisas da Amazônia (INPA), Programa de Pós-Graduação em Entomologia (PPGENT). Av. André Araújo, 2936. CEP \\ 69067-370. Manaus, AM, Brazil. \\ E-mail: rodrigo08vieira@gmail.com
}

\begin{abstract}
The geographic ranges of six species of Asilinae are extended: Anarmostus iopterus Loew, 1860; Cnodalomyia catarinensis Lamas and Mellinger, 2008; Cnodalomyia obtusa Hull, 1962; Eraxasilus pruinosus Carrera, 1959; Glaphyropyga pollinifera Carrera, 1945; Taurhynchus fervidus (Curran, 1934).
\end{abstract}

Asilinae Latreille, 1802 is the most diverse subfamily of Asilidae, including 177 extant genera, and is distributed in all biogeographic regions, except Antarctica (GellerGrimm 2004; Londt 2005; Papavero 2009). Species of the subfamily Asilinae are the most abundant and diverse group of robber flies in the temperate regions of the world, especially the Palearctic (Lehr 1988; Fisher 2009).

Sixty six genera are recognized in the Neotropical region, of which 18 occur in Brazil (Papavero 2009).

According to the catalogue of Neotropical Asilidae (Papavero 2009), the distribution of several species of Asilinae is restricted to type-locality. Herein, new records for six species - Anarmostus iopterus Loew, 1860; Cnodalomyia catarinensis Lamas and Mellinger, 2008; Cnodalomyia obtusa Hull, 1962; Eraxasilus pruinosus Carrera, 1959; Glaphyropyga pollinifera Carrera, 1945; Taurhynchus fervidus (Curran, 1934) - of Asilinae are provided, based on examination of specimens deposited at the Instituto Nacional de Pesquisas da Amazônia INPA and additional specimens from Instituto Oswaldo Cruz - IOC, Museu Nacional do Rio de Janeiro - MNRJ and Instituto Nacional de Biodiversidad - INBIO.

\section{Anarmostus iopterus (Wiedemann, 1828) \\ (Figure 1)}

Distribution: Belize, Honduras, Venezuela, Guyana, Peru (Loreto, Madre de Dios, San Alessandro), Brazil (Pará: Óbidos; Bahia: Porto Seguro), Bolivia (Santa Cruz). New Record: Costa Rica (Guanacaste, Heredia); Brazil (Amazonas) (Table 1).

Material examined: COSTA RICA. Heredia - El Ceibo Biological Station, Braulio Cerrilo, N. P. 400-600m, iv.1990, C. Chaves leg., 527700-256500, INBIO CRI000 19426, 1 male (INBIO). Guanacaste - Pitilla Biological Station, 700m, 9km S, Santa Cecilia, vi.1989, GNP Biodiversity Survey 330200, 380200, INBIO CRI000 007832, 1 female (INBIO). BRAZIL. Amazonas - Manaus, ZF3, BR 174 Highway, Km 41, Reserve 1501, 02²7'26" S, 5945’00" W, 17-31.i.1996,
Rocha and Silva leg., L. E. F., 1 male (INPA). Parque Nacio-

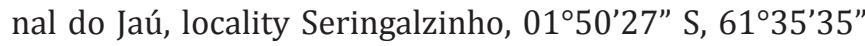
W, 10-24.xi.2003, M.L. Oliveira leg., 1 female (INPA). Novo Aripuanã $05^{\circ} 15^{\prime} 53^{\prime \prime}$ S, 6007'09” W, rainforest, ix.2004, Henriques, Silva and Pena leg., 1 female (INPA). Novo Aripuanã, Sokagakai Reserve, 20.iv.2000, J. Vidal leg., 1 female (INPA). Parque Nacional do Jaú Unini River, locality of Bacaba, 0145'52" S, 6205'11" W, 14-19.vi.1996, A. L. Henriques, J. Vidal and F. Oliveira leg., 1 male (INPA). Reserve Unini, Unini River, 01³7’ S, 6259’ W, 13-28.vii.2004, M. L. Oliveira, L. Aquino and A. Silva-Filho leg., 1 female (INPA). Manaus, INPA, 23.iv.2005, B. M. Oliveira leg., 1 female (INPA). Manaus, Reserve Ducke, 03-07.vii.2001, A. Coletto leg., 1 male (INPA). Manaus, Reserve Ducke, 20.ix.2001, J. A. Rafael and J. F. Vidal leg., 1 female (INPA) Manaus, Antonio leg., 4.xii.1961, 1 male (INPA). BR-17 Highway, Km 19, Manaus, 14.xii.1955, Elias and Roppa leg. 1 female (INPA).

Comments: According to Fisher (2009), this species is widely distributed from Belize to southern Brazil, although there are few specific records for this species in Brazil. Herein, A. iopterus is recorded for the first time in Amazonas state.

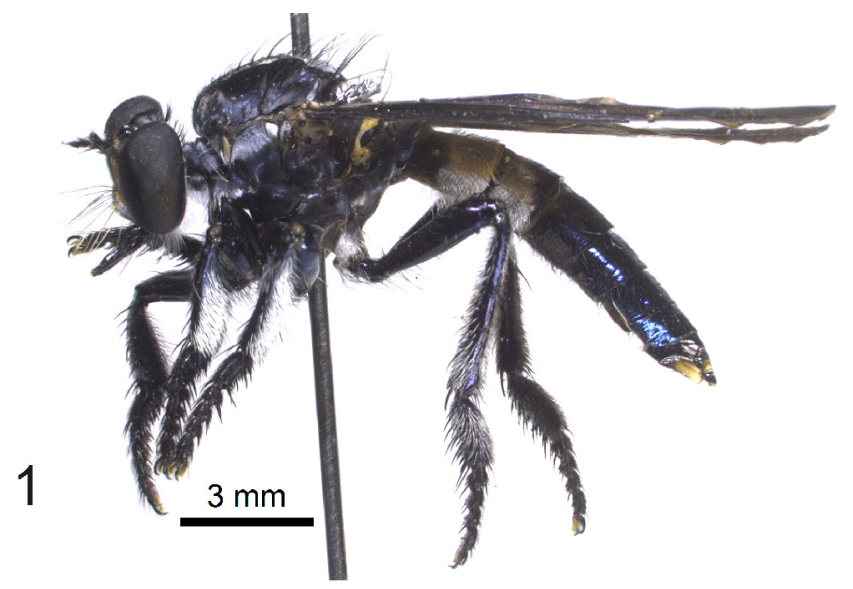

FIGURE 1. Anarmostus iopterus (Wiedemann, 1828), Female Habitus, lateral view. 
TABLE 1. List of species, followed by previously known distribution and author, and new records.

\begin{tabular}{|c|c|c|}
\hline TAXON & PREVIOUSLY KNOWN DISTRIBUTION AND AUTHOR & NEW RECORDS \\
\hline Anarmostus iopterus Loew, 1860 & $\begin{array}{l}\text { Belize (Osten-Saken 1887); Honduras (Williston 1891); Venezuela (Ayala } \\
\text { pers. comm.in Fisher 2009); Guyana (Martin and Papavero 1970); Peru: Loreto } \\
\text { (Papavero 2009); Madre de Dios (Fisher 1985); San Alessandro (Carrera and } \\
\text { d'Andretta 1954); Brazil: Pará: (Walker 1849, Óbidos: Carrera 1960); Bahia } \\
\text { (Porto Seguro: Vieira et al. 2006); Bolivia: Santa Cruz (Papavero 1971) }\end{array}$ & Amazonas \\
\hline $\begin{array}{l}\text { Cnodalomyia catarinensis Lamas and } \\
\text { Mellinger, } 2008\end{array}$ & $\begin{array}{l}\text { Brazil: São Paulo (Campos do Jordão: Lamas and Mellinger 2008); Paraná } \\
\text { (Curitiba: Lamas and Mellinger 2008); Santa Catarina (Nova Teutônia: Lamas } \\
\text { and Mellinger 2008) }\end{array}$ & São Paulo (Bocaína) \\
\hline Cnodalomyia obtusa Hull, 1962 & Brazil: Rio de Janeiro (Alto Itatiaia: Hull 1962) & São Paulo \\
\hline Eraxasilus pruinosus Carrera, 1959 & $\begin{array}{l}\text { Brazil: Goiás (Anápolis, Corumbá de Goiás, Goiânia: Carrera 1959); São Paulo } \\
\text { (Severinia: Carrera 1959; Onda Verde: Carrera and Vulcano 1961) }\end{array}$ & Pará; Mato Grosso \\
\hline Glaphyropyga pollinifera Carrera, 1945 & $\begin{array}{l}\text { Peru: Pando (Madre de Dios: Fisher 1985); Brazil: Pará (Óbidos: Carrera 1960); } \\
\text { Espírito Santo (Linhares: Carrera 1960); São Paulo (São Paulo: Carrera 1945); } \\
\text { Rio de Janeiro: Magé, Nova Iguaçu, Rio de Janeiro, Teresópolis (Carrera 1945); } \\
\text { Bolivia (Beni: Carrera 1959) }\end{array}$ & Acre \\
\hline
\end{tabular}

\section{Cnodalomyia catarinensis Lamas and Mellinger, 2008}

(Figure 2)

Distribution: Brazil (São Paulo: Campos do Jordão; Paraná: Curitiba; Santa Catarina: Nova Teutônia). New municipality record: São Paulo - Bocaína (Table 1).

Material examined: BRAZIL. São Paulo - Bocaína, x.1968, Alvarenga and Seabra leg., 3 males, 3 females (IOC). Bocaína, Fruticultura, 25.xi.1970, M. Alvarenga leg. 1 female (MNRJ).

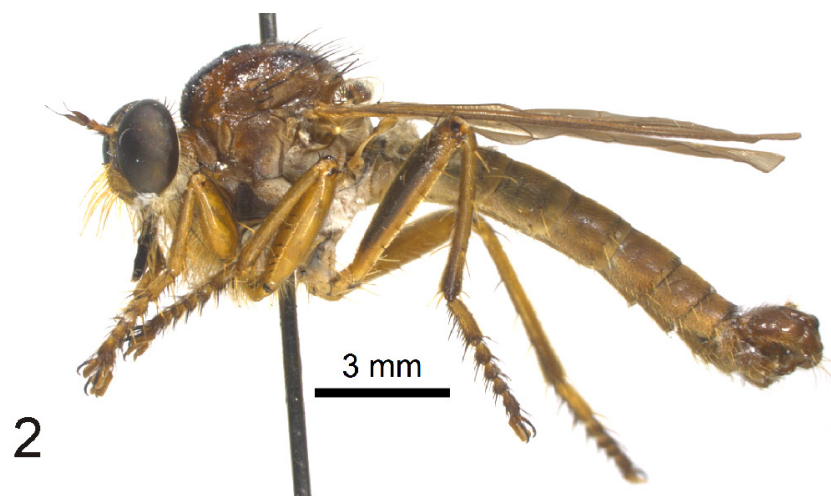

FiguRE 2. Cnodalomyia catarinensis Lamas and Mellinger, 2008, Male Habitus, lateral view.

\section{Cnodalomyia obtusa Hull, 1962}

(Figure 3)

Distribution: Brazil (Rio de Janeiro: Itatiaia). New Record: São Paulo (Table 1).

Material examined: BRAZIL. São Paulo - Bocaína, x.1968, Alvarenga and Seabra leg., 2 male (IOC). Bocaína, Fruticultura, 25.xi.1970, M. Alvarenga leg. 3 males, 2 females (MNRJ).

Comments: According to Lamas and Mellinger (2008), the two species of Cnodalomyia, C. obtusa and $C$. catarinensis are distributed in the highlands of the Atlantic forest. Both species occur at Bocaína-São Paulo. Bocaina is situated at $580 \mathrm{~m}$ altitude in a remaining area of Atlantic forest.

\section{Eraxasilus pruinosus Carrera, 1959}

(Figure 4)

Distribution: Brazil (Goiás: Anápolis, Corumbá de Goiás, Goiânia; São Paulo: Onda Verde, Severinia). New Record: Pará, Mato Grosso (Table 1).

Material examined: BRAZIL. Pará - Alter do Chão, 15-18.ii.1992, J. A. Rafael leg., 1 male (INPA). Conceição do Araguaia, 19-31.i.1983, J. A. Rafael leg., 1 male (INPA). Mato Grosso: Pantanal, 14-17.vi.1991, J.A. Rafael and J. Vidal leg., 2 male, 2 female (INPA).

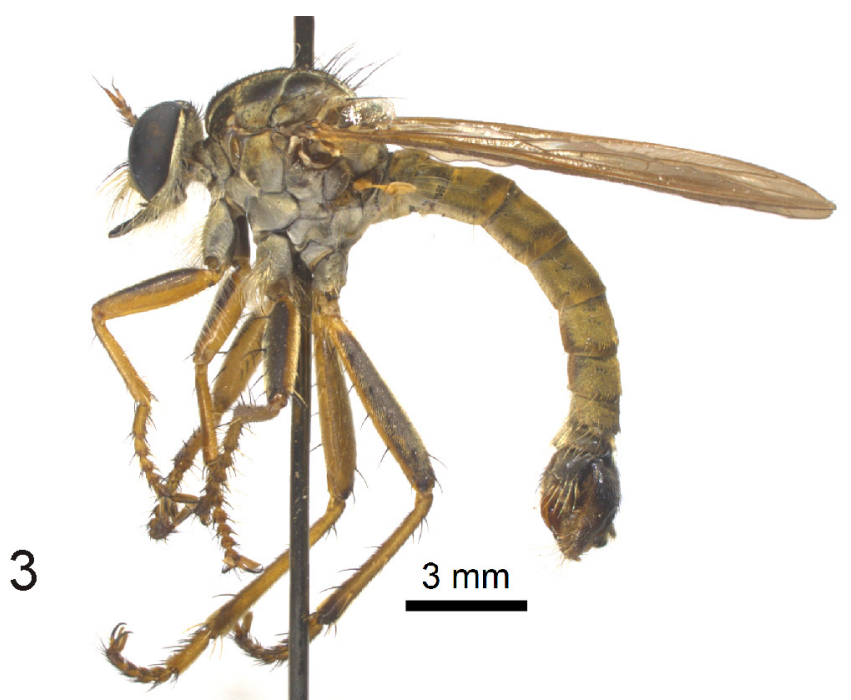

FIGURE 3. Cnodalomyia obtusa Hull, 1962, Male Habitus, lateral view.

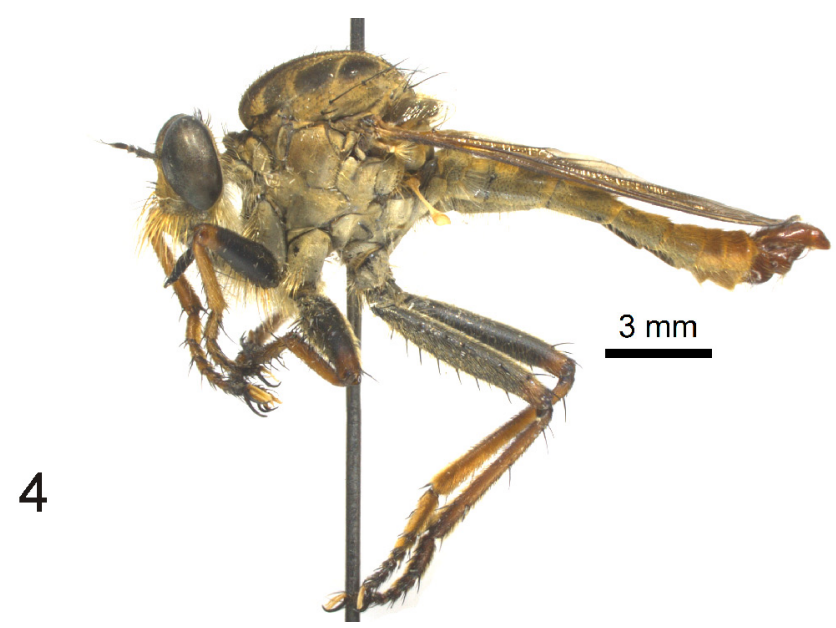

FIgURE 4. Eraxasilus pruinosus Carrera, 1959, Carrera, 1959, Male Habitus, lateral view.

\section{Glaphyropyga pollinifera Carrera, 1945}

(Figure 5)

Distribution: Peru (Pando: Madre de Dios), Brazil (Pará: Óbidos; Espirito Santo: Linhares; Rio de Janeiro: 
Magé, Nova Iguaçu, Rio de Janeiro, Teresópolis; São Paulo: São Paulo), Bolivia (Beni). New Record: Acre. (Table 1).

Material examined: BRAZIL. Acre - Cruzeiro do Sul, Moa River, 07³7’02" S, 7246’15” W, 9-28.xi.1996, J. A. Rafael, J. Vidal and R. L. Menezes leg., 1 male (INPA).

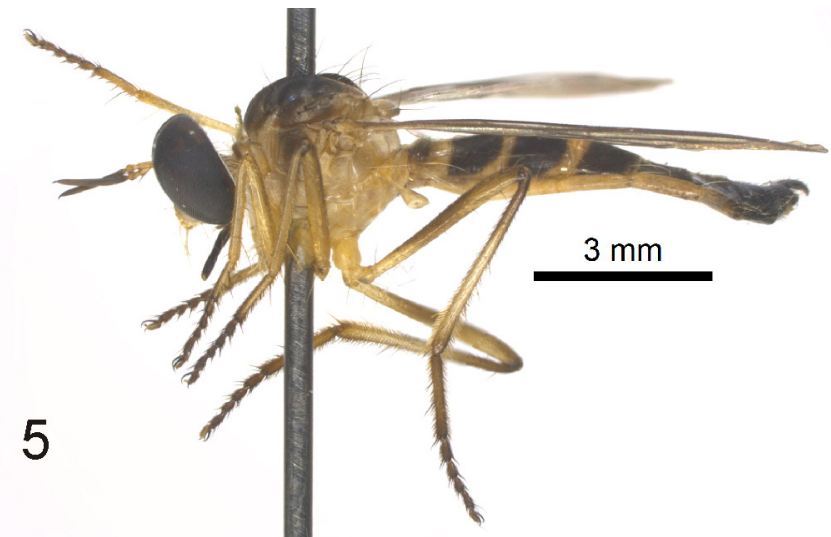

FiguRE 5. Glaphyropyga pollinifera Carrera, 1945, Male Habitus, lateral view.

\section{Taurhynchus fervidus (Curran, 1934)}

(Figure 6)

Distribution: Brazil (São Paulo: Praia Grande). New Record: Amazonas. New municipality record: São Paulo - São Sebastião (Table 1).

Material examined: BRAZIL: Amazonas - Carauari, 505'27" S, 67²10'57" W, vii.2005, Xavier-Filho leg., 2 male (INPA). Presidente Figueiredo, AM-240, Km 24, Community S. Francisco, 15.vii.2002, F. F. Xavier-Filho leg., 1 female (INPA). Japurá River, ix.1982, R. Best leg. 1 male (INPA). Am.1 Highway Km 15, Manaus, 30.vii.1970, A. Faustino leg., 1 female (INPA). Manaus, Bolivia Stream, 19.xii.1957, Elias and Roppa leg., 1 male (INPA). Barcelos $0^{\circ} 28^{\prime} 38^{\prime \prime} \mathrm{N}$, 6328'18" W, vii-viii.2007, A. S. Silva and T. Krolow leg., 1 female (INPA). Barcelos, Demeni River, locality of Pirico, viii.2008, 0¹9'30" S, 6247'21” W, A. Silva and R. Machado, leg., 1 female (INPA). São Paulo - Picinguaba, São Sebastião, 8.x.1985, Leonel, E. leg, 1 female (INPA).

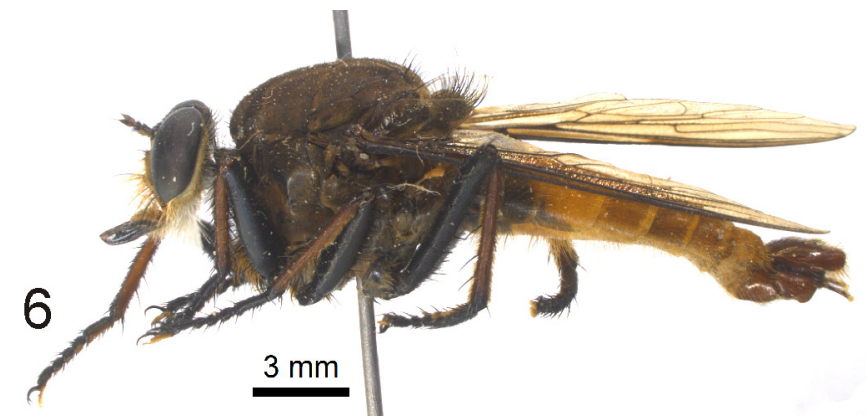

Figure 6. Taurhynchus fervidus (Curran, 1934), Male Habitus, lateral view.
ACKNOWLEDGMENTS: We thank CNPq for the fellowships that have allowed us to complete this study. Fundação de Amparo à Pesquisa do Estado do Amazonas (FAPEAM) and Conselho Nacional de Desenvolvimento Científico e Tecnológico (CNPq) for the financial support (Project PRONEX, Edital 016/2006, Proc. 1437/2007). We also thank Dr. Márcio Félix and Danielle Cerri from Instituto Oswaldo Cruz, Dra. Márcia Couri and Dra. Cátia Mello-Patiu from Museu Nacional of Rio de Janeiro and Manuel Zumbado from INBIO.

\section{Literature Cited}

Carrera, M. 1945. Estudo sobre os gêneros Glaphyropyga e Senoprosopis com descrição de novo gênero e novas espécies. Papéis avulsos do Departamento de Zoologia. Secretária da Agricultura 5(19): 175-192.

Carrera, M. 1947. Segunda relação de alguns Asilidae (Diptera) e suas presas, com a descrição prévias de duas novas espécies. Papéis avulsos do Departamento de Zoologia. Secretária da Agricultura 8(23): 265-271.

Carrera, M. 1959. Sobre Asilídeos neotropicais (Diptera) do Zoologische Sammlung des Bayrischen Staates. Opuscula Zoologica 30: 1-13.

Carrera, M. 1960. Asilidae (Diptera) da coleção Seabra. Arquivos de Zoologia do Estado de São Paulo 11(7): 147-170.

Carrera, M. and M.A.V. d'Andretta. 1954. Asilídeos do Peru (Diptera). Papéis avulsos do Departamento de Zoologia. Secretária da Agricultura 11(9): 63-78.

Carrera, M. and M.A. Vulcano. 1961. Relação de alguns Asilidae (Diptera) e suas presas (IV). Revista Brasileira de Entomologia 10: 67-80.

Curran, C.H. 1934. New American Asilidae (Diptera) III. American Museum Novitates 752: 18.

Fisher, E.M. 1985. A preliminary list of the robberflies (Diptera: Asilidae) of the Tambopata Reserved Zone, Madre de Dios, Peru. Revista Peruana de Entomologia 27: 25-36.

Fisher, E.M. 2009. Asilidae (Robber flies, Assassin flies, Moscas Cazadoras, Moscas Ladronas); p. 585-632 In B.V. Brown, A. Borkent, J.M. Cumming, D.M. Wood, N.E. Woodley and M.A. Zumbado (ed.). Manual of Central American Diptera. Volume I. Ottawa: National Research Council Research Press.

Geller-Grimm, F. 2004. A world catalogue of the genera of the family Asilidae (Diptera). Studia dipterologica 10(2): 473-526.

Hull, F.M. 1962. Robber Flies of the World: The Genera of the Family Asilidae. Bulletin of the United States National Museum, Part 2, 224: 431-906.

Lamas, C.J.E. and G.B. Mellinger. 2008. A new species of Cnodalomyia Hull, 1962 (Diptera, Asilidae, Asilinae) from Brazil. Zootaxa 1676: 37-43.

Lehr, P.A. 1988. Family Asilidae; p. 197-326 In A. Soos and L. Papp (ed.) Catalogue of Palaearctic Diptera 5. Akadémiai Kiadó \& Amsterdam [and others] Budapest: Elsevier.

Londt, J.G.H. 2005. An annotated key to the genera of Afrotropical Apocleinae, with descriptions of six new genera (Diptera: Asilidae). Tijdschrift voor Entomologie 148: 39-62.

Martin, C.H. and N. Papavero. 1970. A catalogue of the Diptera of the Americas south of the United States, Family Asilidae. Boletim Museu de Zoologia, Universidade de São Paulo 35: 1-139.

Osten-Sacken, C.R. 1887. Diptera Fam. Asilidae; p. 167-213 In F. D Godman and O. Salvin (ed.). Biologia Centrali-Americana, ZoologiaInsecta. London: British Museum.

Papavero, N. 1971. Notes on some types of Neotropical Asilidae (Diptera), with descriptions of three new species. Papéis avulsos do Departamento de Zoologia 25: 19-29.

Papavero, N. 2009. Catalogue of Neotropical Diptera. Asilidae. Neotropical Diptera 17: 1-179.

Vieira, R., I. Castro, D. Almeida, E. Alvim, and F. Bravo. 2006. Asilidae (Diptera) da Bahia, Brasil: sinopse das espécies e chave de identificação. Sitientibus Série Ciências Biológicas 6(4): 243-256.

Walker, F. 1849. List of the specimens of dipterous insects in the collection of the British Museum, Part 2. London: London: British Museum. 253 p.

Williston, S.W. 1891. Catalogue of the described species of South American Asilidae. Transactions of the American Entomological Society 18: 67-91.

RECEIVED: March 2012

ACCEPTED: June 2012

Published ONLINE: August 2012

EDITORIAL RESPONSIBILITY: Ricardo Solar 